\title{
Komunikasi Dakwah TGH. Mukhtar Amin dalam Membangun Semangat Berhaji di Majelis Ta'lim al-Mukhtariah Desa Pemenang Timur
}

\author{
M. Zaki Abdillah, ${ }^{1}$ Ishanan $^{2}$ \\ 1.2. Program Studi Komunikasi Penyiaran Islam, Fakultas Agama Islam \\ Universitas Muhammadiyah Mataram,83115, Indonesia \\ Iibanee@gmail.com² ${ }^{2}$ shanannans@gmail.com
}

INFOARTIKEL

Riwayat Artikel:

DiterimaJuli 2018

Direvisi Agustus 2018

Disetujui September 2018
ABSTRAKSI

\begin{abstract}
Abstrak:Ada dua persoalan yang dikaji dalam penelitian ini yaitu: (1) Bagaimana Komunikasi Dakwah TGH. Mukhtar Amin dalam membangun semangat berhaji di Majelis Ta'lim Al-Mukhtariah Desa Pemenang Timur? (2) Apa aspek jamaah yang disentuh oleh TGH. Mukhtar Amin dalam membangun semangat berhaji di Majelis Ta'lim Al-Mukhtariah Desa Pemenang Timur? Untuk menjawab persoalan tersebut peneliti menggunakan metode kualitatif deskriptif yang berorientasi pada studi tokoh. Dengan menggunakan pendekatan komunikasi, peneliti berusaha menjelaskan model komunikasi dakwah TGH. Mukhtar Amin dalam membangun semangat berhaji di Desa Pemenang Timur. Hasil penelitian ini menunjukkan bahwa, (1) T.G.H. Mukhtar Amin membangun semangat berhaji jamaah Majelis Ta'lim al-Mukhtariah di Desa Pemenang Timur dengan pendekatan komunikasi persuasif. (2) Aspek kognitif, afektif dan behavioral adalah tiga aspek utama jamaah yang disentuh oleh TGH. Mukhtar Amin dalam membangun semangat berhaji jamaah Majelis Ta'lim al-Mukhtariahdi Desa Pemenang Timur.
\end{abstract}

Abstract: There are two problems that are examined in this study, which are: (1) How is Da'wah Communication of the TGH Mukhtar Amin in building the spirit of pilgrimage in the Ta'lim AlMukhtariah Assembly at the East Pemenang Village? (2) What are the aspects of pilgrims touched by TGH. Mukhtar Amin in building the spirit of pilgrimage in the Ta'lim Al-Mukhtariah Assembly at the East Pemenang Village?. To answer these problems, researchers used descriptive qualitative methods that were oriented towards character studies. By using a communication approach, researchers try to explain the communication model of the mission of the TGH Mukhtar Amin in building the spirit of hajj at the East Pemenang Village. The results of this study indicate that, (1) T.G.H. Mukhtar Amin built a spirit of hajj pilgrimage to the Majelis Ta'lim alMukhtariah congregation at the East Pemenang Village with a persuasive communication approach. (2) Cognitive, affective and behavioral aspects are the three main aspects of worshipers touched by TGH. Mukhtar Amin in building the spirit of the pilgrimage of the Majelis Ta'lim al-Mukhtariah congregation at the East Pemenang Village

\section{Pendahuluan}

Setiap agama yang menyadari keberlanjutan agamanya, senantiasa ditugaskan oleh pendirinya untuk meneruskan "kharisma" agama yang dianut, secara teratur dan tertib kepada para 
pengikutnya. ${ }^{1}$ Agama semata, tentu tidak akan mampu memberikan perannya bagi masyarakat, tanpa disertai dengan peran yang sama dari pemeluk agama itu sendiri. Oleh karenanya, peran para pemimpin agama dalam mengaplikasikan nilai-nilai keagamaannya begitu penting. Hal ini dilakukan sebagai media dalam memberikan wawasan, pemahaman dan keteladanan dalam menjalankan ajaran agama di tengah masyarakat.

Islam sebagai bagian dari agama samawi dengan misi penyebaran yang jelas, juga menekankan pentingnya peran-peran para penganutnya untuk menyebarkan ajarannya. ${ }^{2}$ Nabi Muhammad SAW sebagai pembawa ajaran Islam telah memerintahkan kepada umatnya untuk menyampaikan setiap ajaran dari agama Islam kepada umat manusia. Dalam hal ini, para ulama lah yang secara garis besar memikul amanah sebagai pewaris para Nabi. ${ }^{3}$ Besarnya peran ulama dalam melanjutkan misi dakwah, juga dibarengi dengan sikap masyarakat yang begitu menghormati dan memuliakan mereka, mengingat, ulama dikenal konsistendalam mengamalkan ajaran-ajaran Islam. ${ }^{4}$

Dalam konteks masyarakat Sasak, tuan guru dianggap sebagai alim ulama, adalah fungsionaris agama Islam yang menjadi panutan masyarakat. Mereka adalah kelompok sosial elit yang merefresentasikan pengetahuan Islam yang tinggi, serta mereka diakui sebagai penyebar dan pemelihara ajaran Islam, khususnya dalam menegakkan amar ma'ruf nahi munkar. ${ }^{5}$

Dalam menjalankan aktivitas dakwah, para tuan guru secara personal memiliki keunikan pendekatan, dan metode tertentu, salah satunya jika ditinjau dari aspek komunikasi. Salah seorang tuan guru yang memiliki keunikan dalam mengkomunikasikan dakwah Islam adalahTGH. Mukhtar Amin, di Dusun Trengan Lauk, Desa Pemenang Timur, Kecamatan Pemenang, Kabupaten Lombok Utara. Melalui aktivitas pengajian yang secara rutin diadakan di MajelisTa'lim al-Mukhtariah, masyarkat datang dari berbagai latar belakang jamaah.

Dalam konteks dakwah dan komunikasi, adalah unik pada TGH. Mukhtar Amin bagi peneliti, yang mana hal tersebut juga akan menjadi fokus kajian peneliti, yakni kemampuannya dalam mempersuasi masyarakat tentang pentingnya menjalankan ibadah haji. Fenomena ini didasarkan pada keadaan masyarakat yang hadir ke MajelisTa'lim al-Mukhtariah selalu menjadikan ibadah haji sebagai prioritas utama untuk segera dilakukan. Padahal ibadah haji bukanlah ibadah yang mudah. Apalagi bila diklasifikasikan, jamaah beliau umumnya adalah orang-orang yang secara pendidikan formal rendah, dan sudah tua dari segi usia.

Melihat dari kaca pandang komunikasi, tentu sifat komunikatif TGH. Mukhtar Amin dalam mengakomodasi jamaahnya yang notabene adalah orang-orang yang secara pendidikan formal tertinggal, adalah fenomena yang unik. Selain itu, ibadah haji sendiri adalah ibadah yang cukup berat, karena selain harus siap secara moril, juga harus siap secara materil. Maka, kemampuan TGH. Mukhtar Amin dalam mempersuasi jamaahnya untuk membangun motivasi berhaji adalah sesuatu yang logis bila dijadikan sebagai ranah penelitian. Mengingat, tidak semua da'i mampu mengkomunikan hal yang sama, terutama dengan kondisi masyarakat yang rendah secara pendidikan dan tua secara usia.

Oleh karena itu, peneliti akan berusaha mengkaji secara mendalam bagaimana komunikasi dakwah TGH. Mukhtar Amin dalam kaitannya dengan upaya membangun semangat masyarakat untuk berhaji, ditinjau dari aspek komunikasi. Hal ini didasarkan pada kemampuannya dalam mengemas dan mencermati masyarakat yang didakwahi sesuai dengan realitas masyarakat itu sendiri.

\footnotetext{
${ }^{1}$ Hendropuspito, Sosiologi Agama, (Yogyakarta: Penerbit Kanisius, 1983), 121

${ }^{2}$ Ilyas Ismail \& Prio Hotman, Filsafat Dakwah: Rekayasa Membangun Agama dan Peradaban Islam, (Jakarta: Kencana Prenada Media Group, 2011)

3 (At-Tirmi>zi No. 2681)

${ }^{4}$ Anwar Arifin, Dakwah Kontemporer: Sebuah Studi Komunikasi, (Yogyakarta: Graha Ilmu, 2011), 4.

${ }^{5}$ Asnawi, Agama dan Paradigma Sosial: Menyingkap Pemahaman Masyarakat Sasak Tentang Taqdir Allah dan Kematian Bayi, (Jakarta: Sentra Media, 2006),23.
} 


\section{Kajian Pustaka}

\section{A. Konsep Dasar Komunikasi dan Dakwah}

Kata komunikasi atau communication dalam bahasa Inggrisnya, berasal dari bahasa Latin communis yang memiliki arti sama. Selanjutnya ada juga kata communico, communication, atau communicare yang memiliki arti "membuat sama", atau to make common. Dari beberapa istilah yang ada, kata communis yang paling sering digunakan sebagai akar kata-kata Latin yang mirip dengan kata awal lahirnya istilah komunikasi. ${ }^{6}$

Secara sederhana, komunikasi dapat didefinisikan sebagai proses penyampaian pesan dari komunikator kepada komunikan melalui media tertentu dan dengan efek tertentu pula. ${ }^{7}$ Komunikasi dianggap berhasil manakala pesan yang disampaikan dimaknai sama oleh komunikator dan komunikan sesuai dengan kerangka acuan yang ada. Sehingga, komunikasi bisa dipahami sebagai kegiatan penyampaian pesan dari satu ke pihak lain dengan tujuan mencapai kesepakatan bersama dalam memaknai pesan-pesan yang dipertukarkan. ${ }^{8}$

Berbeda dengan komunikasi, kata "dakwah" berasal dari bahasa Arab yang berarti, panggilan, seruan, dan ajakan. Dalam term Ilmu Nahwu, kata "dakwah" adalah bentuk masdar dari kata awal, "da'a-yad'u-dakwatan", yang berarti upaya memanggil, menyeru, dan mengajak manusia ke jalan Allah. Orang yang berdakwah disebut dengan istilah Da'i dan orang yang menjadi sasaran dakwah disebut dengan istilah Mad'u.'

Dalam kegiatan atau aktivitas dakwah, yang perlu menjadi perhatian adalah, adanya unsurunsur (komponen) penting yang terkandung di dalamnya. Komponen itulah yang mendukung efektifitas keberhasilan dakwah, manakala semua komponen tersebut saling melengkapi satu sama lain. ${ }^{10}$ Dakwah sendiri sebagai sebuah aktifitas adalah usaha untuk mempengaruhi pendapat, pandangan, sikap ataupun tingkah laku seseorang.

Secara umum, untuk mempengaruhi orang ada dua hal yang bisa ditempuh: ${ }^{11}$ Pertama, koersif yaitu dengan cara paksaan bahkan disertai dengan terror yang dapat menekan batin. Kedua, persuasif yaitu tanpa adanya paksaan dengan mempengaruhi jiwa seseorang sehingga dapat membangkitkan kesadarannya untuk menerima dan menerima suatu tindakan. ${ }^{12}$ Sehingga dapat dikatakan Dakwah Persuasif adalah proses kegiatan yang mempengaruhi jiwa seseorang (mad'u) sehingga timbul kesadarannya sendiri untuk mengikuti ajakan pendakwah (da'i) dengan cara halus atau tanpa paksaan.

\section{B. Pengertian Komunikasi Dakwah}

Sebagai mahkluk sosial, kegiatan sehari- hari selalu berhubungan dengan orang lain dalam upaya pemenuhan kebutuhan hidup. ${ }^{13}$ Demikian juga dengan komunikasi, ia merupakan bagian integral kehidupan manusia, apapun statusnya di masyarakat. Komunikasi adalah hubungan kontak antar dan antara manusia baik individu maupun kelompok. ${ }^{14}$ Wahyu Ilaihi mengutip pendapat Ahmad Mubarak bahwa pada dasarnya, kegiatan dakwah adalah kegiatan komunikasi, di mana da'i mengomunikasikan pesan dakwah kepada mad'u, baik dilakukan secara perorangan, ataupun kelompok. ${ }^{15}$

\footnotetext{
${ }^{6}$ Deddy Mulyana, Ilmu Komunikasi; Suatu Pengantar, Cet ke-12 (Bandung: PT Remaja Rosdakarya, 2008$), 46$.

${ }^{7}$ Wahyu Ilaihi, Komunikasi Dakwah, (Bandung, PT Remaja Rosdakarya, 2010), 4.

${ }^{8}$ Ibid.

${ }^{9}$ Wahyu Ilaihi, Komunikasi Dakwah..., 19.

${ }^{10}$ Ibid...,19.

${ }^{11}$ Ali Aziz, Ilmu Dakwah, (Jakarta: Kencana, 2009),446

${ }^{12}$ Muhammad Sulthon, Desain Ilmu DakwahKajian Ontologis, Epistimologis, dan Aksiologis, (Yogyakarta: Pustaka Pelajar,2003), 16.

${ }^{13}$ Bandingkan dengan Rulli Nasrullah, Komunikasi Antar Budaya: Di Era Budaya Siber, (Jakarta: Kencana Prenadamedia Group, 2014),

${ }^{14}$ H. A.W. Widjadja, Komunikasi: Komunikasi dan Hubungan Masyarakat, (Jakarta: PT Bumi Aksara, 2002), h. 1.

${ }^{15}$ Wahyu Ilaihi, Komunikasi Dakwah..., 14
} 
Dalam kajian yang lebih mendalam, perbedaan yang ada hanyalah pesan yang disampaikan, yaitu ajaran Islam dan komuniator dalam konteks dakwah diharuskan memiliki syarat dan spesifikasi kriteria tersendiri. ${ }^{16}$ Selain itu, jika biasanya dalam komunikasi biasa yang rutin dilakukan, tidak terlalu peduli pada motivasi ataupun tujuan yang dimaksud, maka dalam komunikasi dakwah, hal tersebut benar-benar dikaitkan dengan tujuan dakwah, baik itu secara makro maupun mikro. ${ }^{17}$

\section{Komunikasi Persuasif}

Proses komunikasi persuasif bertujuan untuk mengubah sikap, pendapat dan prilaku. Istilah persuasif bersumber dari perkataan latin "persuasion" memiliki kata kerja "persuadere" yang berarti membujuk, mengajak, atau merayu, dalam bahasa Inggris "persuation" ${ }^{18}$ Persuation dapat diartikan sebagai membujuk, merayu, meyakinkan, dan sebagainya. ${ }^{19}$ Para ahli komunikasi sering menekankan bahwasanya persuasif adalah kegiatan psikologis. Dalam pengertian yang lebih luas, persuasif dapat diartikan sebagai suatu proses mempengaruhi pendapat dan tindakan orang dengan menggunakan manipulasi psikologis, sehingga orang tersebut bertindak atas kehendaknya sendiri. Penegasan tersebut untuk membedakan dengan koersi. ${ }^{20}$

Akibat yang ditimbulkan dari kegiatan persuasive adalah sebuah nilai kesadaran, kerelaan disertai perasaan senang. Sedangkan kegiatan coersia adalah perubahan sikap, pendapat, atau prilaku dengan perasaan terpaksa karena diancam, yang menimbulkan perasaan tak senang. Komunikasi persuasif akan menimbulkan dampak yang lebih tinggi jika dibandingkan dengan komunikasi informatif, yakni dampak kognitif, afektif, dan bahkan behavioral. ${ }^{21}$

Pernyataan di atas senada dengan apa yang juga dimaksudkan oleh Everet M. Rogers dan Shoemaker melalui teori homofili dan heterofilinya. Manakala usaha empati dilakukan dalam proses komunikasi, seorang komunikator bisa menciptakan kebersamaan-kebersamaan, baik fisik maupun mental. ${ }^{22}$

\section{Metode Penelitian}

\section{Bentuk Penelitian}

Dalam melaksankan penelitian ini, peneliti menggunakan metode penelitian kualitatif dengan pendekatan komunikasi persuasif. Metode penelitian kualitatif juga sering disebut metode penelitian naturalistik. Hal ini didasarkan pada kondisinya yang alamiah. Artinya, apa yang menjadi objek penelitian bukanlah sesuatu yang dimanipulasi, karena memang berkembang apa adanya. ${ }^{23}$

\section{E. Objek Penelitian}

Yang menjadi objek penelitian dalam penelitian ini adalah TGH. Mukhtar Amin. Sehingga penelitian ini adalah berpusat pada studi tokoh.

\section{F. Instrumen Penelitian}

Dalam penelitian ini yang menjadi instrumen utama adalah peneliti sendiri.

\section{G. Sampel Data}

Sumber data utama dalam penelitian ini ialah hasil wawancara dan fenomena. Adapun data sekunder ialah dokumen-dokumen yang terkait dengan subjek penelitian.

\footnotetext{
${ }^{16}$ A.W. Widjadja, Komunikasi: Komunikasi dan Hubungan Masyarakat, (Jakarta: PT Bumi Aksara, 2002) hal 3.

${ }^{17} \mathrm{Ibid}$.

${ }^{18}$ Wahyu Ilaihi, h. 125

${ }^{19}$ Moh. Ali Aziz, Ilmu Dakwah, (Jakarta: Kencana, 2009),446.

${ }^{20}$ Muhammad Sulthon, Desain Ilmu DakwahKajian Ontologis, Epistimologis, dan Aksiologis, (Yogyakarta: Pustaka Pelajar,2003), 16.

${ }^{21}$ Wahyu Ilaihi, Komunikasi..., h. 125

${ }^{22}$ Anwar Arifin, Dakwah Kontemporer..., 77.

${ }^{23}$ Imam Suprayogo, Metodologi Penelitian Sosial Agama, (Bandung: Rosdakarya, 2001), 163.
} 


\section{H. Teknik Pengumpulan Data}

Teknik pengumpulan data dalam penelitian ini ialah wawancara, observasi dan dokumentasi. Teknik wawancara dan observasi dilakukan bagi memudahkan interaksi antara peneliti dengan kelompok yang menjadi objek penelitian. Adapun telaah dokumen diperlukan untuk melengkapi data yang diperlukan.

Dalam penelitian ini, teknik wawancara yang digunakan adalah wawancara mendalam dengan mengajukan beberapa pertanyaan terkait fokus permasalahan. Sedangkan pemilihan sampel dilakukan dengan cara purposive sampling sehingga memenuhi keperluan penelitian.

\section{Teknik Analisis Data}

Setelah semua data terkumpul maka langkah seterusnya adalah mengolah dan menganalisa data dengan cara menyusun data ke dalam kategori, melakukan sintesa, menyusun ke dalam pola lalu membuat kesimpulan sehingga mudah difahami.

\section{J. Tempo Penelitian}

Penelitian ini dilakukan selama enam (6) bulan mulai dari bulan Maret sampai bulan Agustus.

\section{Penyajian dan Analisis Data}

\section{1) Penyajian Data}

\section{K. Dakwah TGH. Mukhtar Amin di Majelis Ta'lim Al-Mukhtariah Desa Pemenang Timur}

Secara teoretis, tuan guru adalah kelompok sosial elit yang merefresentasikan pengetahuan Islam yang tinggi, serta mereka diakui sebagai penyebar dan pemelihara ajaran Islam, khususnya dalam menegakkan amar ma'ruf nahi munkar. ${ }^{24}$

Semenjak TGH. Mukhtar Amin menimba ilmu di Tanah Makah tahun 1982, dan pulang ke kampung halamannya pada tahun 1993, geliat dakwah langsung digalakkan, melalui masjid dan musalla. ${ }^{25}$ Adanya antusiasme masyarakat yang luar biasa, membuat TGH. Mukhtar Amin membangun masjlis ta'lim (Al-Mukhtariah) sebagai sarana pengajian. Tujuannya adalah, untuk memusatkan praktek dakwah guna proses dakwah dan pengajaran agama Islam yang lebih terpola dengan baik. Di samping itu, dakwah juga dilakukan di berbagai tempat lain, melalui kegiatankegiatan keagamaan yang sifatnya undangan masyarakat dan tugas TGH. Mukhtar Amin sebagai anggota MUI bidang Hukum dan Fatwa di Kabupaten Lombok Utara.

Ada bebarapa aktifitas dakwah yang dilakukan TGH. Mukhtar di Majelis Taklim alMukhtariah yakni:

1. Pengajian harian. Pengajian harian biasanya diadakan setelah sholat subuh Pengajian ini umumnya difokuskan pada persoalan-persoalan fiqih. Sasarannya adalah masyarakat sekitaran tempat tinggal TGH. Mukhtar Amin. Pada pelaksanaannya, pengajian ini lebih banyak diadakan di Masjid Nurul Yaqin, yang memang berdekatan dengan Majelis alMukhtariah.

2. Pengajian mingguan. Pengajian mingguan secara khusus diadakan setiap hari jum'at. Biasanya dimulai dari pagi sampai menjelang sholat jum'at. Sasaran dari pengajian ini sifatnya adalah masyarakat umum yang ada di kecamatan Pemenang, walaupun pada prosesnya, banyak juga jamaah pengajian yang dting dari berbagai kecamatan di Lombok Utara.Tema pokok yang ditekankan oleh TGH. Mukhtar Amin dalam pengajian mingguan ini adalah kajian-kajian fiqih, yang secara khusus di dominasi oleh kajian tentang Ibadah haji.

\footnotetext{
${ }^{24}$ Asnawi, Agama dan Paradigma Sosial: Menyingkap Pemahaman Masyarakat Sasak Tentang Taqdir Allah dan Kematian Bayi, (Jakarta: Sentra Media, 2006),23.

${ }^{25}$ Asnawi, Agama Dan Paradigm Sosial: Menyingkap Pemahaman Masyarakat Sasak tentang Takdir Allah dan Kematian Bayi, (Jakarta: Sentra Media, 2006), 23
} 
3. Pengajian Bulanan. Selain pengajian harian dan mingguan, ada juga pengajian yang sifatnya bulanan. Sasarannya adalah para remaja dan pemuda yang ada di Dusun Trengan Lauk, yakni dusun tempat tinggal TGH. Mukhtar Amin.

\section{Dakwah TGH.Mukhtar Amin tentang Ibadah Haji}

Adapun terkait dengan penyampaian materi haji oleh TGH. Mukhtar Amin di Majelis Tak'lim Al-Mukhtariah, bisa digambarkan sebagai berikut:

1. Waktu pengajian. Materi tentang ibadah haji secara khusus di kaji setiap hari jum'at, walaupun dalam prosesnya, materi-materi rukun Islam yang lain juga dibahas, tapi TGH. Mukhtar Amin memberikan perhatian lebih pada materi haji. Pengajian biasanya dimulai pukul $8.00 \mathrm{~s} / \mathrm{d}$ menjelang sholat jumat.

2. Suasana pengajian. Pengajian berlangsung dengan suasana yang santai. Para jamaah biasanya mengambil tempat duduk secara melingkar, dan sebagian lagi duduk dengan bentuk shaf, dengan jamaah laki-laki biasanya di depan dan jamaah perempuan berada di belakang. TGH. Mukhtar Amin sendiri mengambil tempat duduk yang sejajar denganpara jamaah yang ada di depan. Tampilannya sederhana dan tidak mencolok.

3. Cara penyampaian. TGH. Mukhtar Amin biasanya menyampaikan materi tentang ibadah haji dengan merujuk pada teks kitab kuning yang berbahasa Arab. Kemudian ia menterjemahkan bahasa Arab itu ke dalam bahasa Indonesia, dan akan ia tekankan lagi pengulangan maknanya dengan menggunakan bahasa Sasak. Setiap selesai membahas sebuah topik, TGH. Mukhtar akan mempersilahkan para jamaah untuk bertanya seputar materi yang dibahas.

\section{2) Analisis Data}

\section{A. Komunikasi TGH. Muhktar Amin dalam Membangun Semangat Berhaji}

Tidak mudah untuk membuat sebuah komunikasi berjalan dengan menghasilkan kesepakatan secara utuh sesuai dengan tujuannya.Agar komunikasi mencapai tujuan dan sasarannya, maka perlu dilakukan perencanaan yang matang oleh komunikatoragar pesan yang ia sampaikan mengena kepada komunikan. Hal yang paling mendasar dalam konteks ini adalah, komunikator harus tau benar kondisi si komunikan, sehingga ia mampu menempatkan dirinya, dan membangun komunikasi yang sesuai dengan keadaan dan keberadaan komunikan.

Steward L Tubbs, sebagaimana dikutip oleh Wahyu Ilaihi, mengemukakan bahwa setidaknyaada lima indikasi yang menunjukkan komunikasi bisa dikatakan efektif: ${ }^{26}$

1. Pengertian, penerimaan yang cermat dari sisi stimuli seperti apa yang dimaksud oleh komunikator.

2. Kesenangan, komunikasi ini juga disebut dengan komunikasi fasis (phatic communiation) yang dimaksudkan untuk menimbulkan kesenangan. Komunikasi menjadikan hubungan antar individu menjadi hangat, akrab dan menyenangkan.

3. Pengaruh pada sikap, komunikasi juga sering dilakukan untuk mempengaruhi orang lain, seperti seorang khatib yang ingin membangkitkan sikap keagamaan dan mendorong jamaah dapat beribadah dengan baik, atau seorang politisi yang ingin menciptakan citra yang baik kepada publik pemiliknya, dan lain-lain.

4. Hubungan sosial yang makin baik, komunikasi juga ditunjukkan untuk menumbuhkan hubungan sosial yang baik. Manusia adalah makhluk sosial yang tidak dapat bertahan hidup 
sendiri, untuk itu manusia selalu berkeinginan untuk berhubungan dengan orang lain secara positif.

5. Tindakan, tindakan persuasi dalam komunikasi digunakan untuk mempengaruhi sikap persuasif, juga diperlukan untuk memperoleh tindakan yang dikehendaki komunikator. Dalam hal ini, efektifitas komunikasi biasanya diukur dari tindakan nyata oleh komunikan.

Sebagai kegiatan yang memasarkan sebuah ideologi, maka dakwah juga butuh trategipemasaran. ${ }^{27}$ Ajaran yang baik dan benar, perlu juga didukung dengan pengajaran yang benar. Dalam menghadapi realitas masyarakat yang beragam, tuan guru juga dituntut untuk mampu melakukan kegiatan dakwah dengan berbagai macam pendekatan, metode maupun strateginya.

T.G.H. Mukhtar Amin, sadar betul akan realitas jamaahnya yang secara sosial, hadir dari berbagai macam latar belakang pemahaman. Sehingga perlu strategi khusus untuk memberikan pemahaman yang benar terhadap sebuah persoalan keagamaan, termasuk ajaran Islam tentang ibadah haji.

TGH. Mukhtar Amin banyak menggunakan komunikasi persuasif dalam melaksanakan aktifitas dakwahnya. Sebelum memulai aktifitas dakwah, ia selalu melihat situasi dan kondisi mad'u yang dihadapinya. Bagaimana pendidikan mereka, usia mereka, ataupun berdasarkan kombinasi di antara keduanya, sehingga barulah diputuskan materi apa serta bahasa seperti apa yang layak dan sebaiknya digunakan.

Sejalan dengan sifatnya yang tidak memaksa, tujuan utama dari komunikasi persuasif adalah mempengaruhi pendapat dan tindakan orang melalui manipulasi psikologis, supaya orang bertindak atas kehendaknya sendiri. ${ }^{28}$ Sehingga, akibat yang ditimbulkan adalah sebuah nilai kesadaran, kerelaan disertai perasaan senang untuk melakukan sesuatu. Artinya, jika komunikasi persuasif dihubungkan dengan kerangka dakwah, akan terbentuk komunikasi yang senantiasa berorientasi pada segi-segi psikologis mad'u dalam rangka membangkitkan kesadaran mereka untuk menerima dan melaksanakan ajaran Islam.

Ibadah haji, dalam pandangan TGH. Mukhtar Amin, adalah sesuatu yang berat untuk dilaksanakan. Mengingat syaratnya yang harus mengikutsertakan kemampuan finansial sebagai beberapa indikatornya. Hal ini secara umum, tidak semua orang mampu memenuhinya. Di satu sisi, ibadah haji adalah bagian dari kesempurnaan rukun iman, di sisi lain syaratnya yang berat terkadang tidak mampu dipenuhi oleh setiap orang. ${ }^{29}$

Dalam konteks ini, TGH. Mukhtar Amin tidak memaksa jamaah untuk mati-matian mencari uang untuk segera berhaji, karena ia adalah bagian dari rukun iman. Tapi hal utama yang diberikan kepada masyarakat adalah pemahan tentang arti penting mengetahui ilmu berhaji.

Penyampaian mengenai ibadah haji ini pun disesuaikan dengan tingkat pengetahuan jamaah di Majelis Al-Mukhtariah. Terutama dalam kontek bahasa dakwah. Walapun referensi utama dari materi ibadah haji adalah kitab-kitab kuning, tapi dalam prakteknya TGH. Mukhtar Aminmenyesuaikan dengan latar belakang pengetahuan jamaahnya.

Dalam hal ini, menarik kiranya apa yang dikemukan oleh Azyumardi Azra, Atthariqatu ahammu min al-maddah (metode lebih penting dari pada materi). ${ }^{30}$ Dalam pandangannya, Azyumardi menjelaskan bahwa, pernyataan ini semakin sejalan jika dikaitkan dalam lingkup dakwah, terutama terkait bagaimana dakwah Islam dilakukan. Mengingat, sebaik apapun materi dakwah, jika disampaikan dengan cara yang mengabaikan kondisi sosio-psikologi manusia, bisa

\footnotetext{
${ }^{27}$ Ali Aziz, Ilmu..., 345

${ }^{28}$ Muhammad Sulthon, Desain Ilmu DakwahKajian Ontologis, Epistimologis, dan Aksiologis, (Yogyakarta: Pustaka Pelajar,2003), 16.

${ }^{29}$ Wawancara, Mukhtar Amin, 10 September 2018

${ }^{30}$ Azyumardi Azra "Pengantar" dalam Acep Aripudin, Pengembangan...,vii
} 
jadi materi itu akan ditolak dan tidak dipahami oleh komunikan. Bahwa untuk menciptakan komunikasi yang efektif, komunikator juga harus mampu menempatkan dirinya untuk membentuk sebuah kesamaan persepsi dengan komunikannya.

Secara teoretis, seorang da'i memang dituntut untuk bisa membaca situasi dan kondisi mad'u nya. Sehingga pesan yang disampaikan bisa dipahami dan dimengerti oleh mad'u. Keberhasilan sebuah pesan bisa diterima atau tidak, juga bergantung pada komunikatornya. Sehingga, kemampuan komunikator menempatkan diri pada situasi dan kondisi orang lain adalah bagian yang tidak terpisahkan dari bisa dan tidaknya pesan dakwah diterima. Dalam hal ini komunikator harus bisa mengandaikan diri, bagaimana kalau ia yang berada pada kondisi dan posisi komunikan. $^{31}$

\section{B. Aspek Jamaah yang Disentuh oleh TGH. Mukhtar Amin dalam Membangun Semangat Berhaji}

Menurut TGH. Mukhtar Amin, ada persepsi yang salah dari masyarakat dalam memaknai ibadah haji. Haji sering dianggap sebagai sebuah kewajiban yang hanya dibebankan kepada orang Islam yang kaya saja, padahal, kewajiban yang sama juga berlaku untuk yang tidak mampu. Paling tidak, dengan cara belajar ilmu manasik haji. Pandangan ini berawal dari realitas masyarakat yang belajar ilmu manasik haji hanya pada saat akan berangkat haji saja, tanpa ada keinginan untuk belajar sebelumnya. ${ }^{32}$

Maka hal pertama yang dilakukan oleh TGH. Mukhtar Amin adalah, memberikan pemahaman yang benar tentang memaknai haji.Haji tak lagi dipandang hanya sebagai ibadah yang dilakukan manakala merasa mampu saja, walaupun belum merasa mampu, paling tidak belajar dulu ilmu haji itu. Mampu menunaikan atau tidaknya, bergantung kepada panggilan Allah SWT. Lambat laun, hal ini dipahmi oleh masyarakat sehingga, saat penelitian ini dilakukan, jamaah TGH. Mukhtar Amin sebagian besar sudah ikut mendaftarkan diri mereka untuk menunaikan ibadah haji.

Dalam kaitannya dengan aspek teoretis, maka apa yang TGH. Mukhtar Amin lakukan sejalan dengan konsep efek pesan. Sebagaimana dijelaskan di atas bahwa, komunikasi persuasif adalah komunikasi yang bertujuan untuk mengubah sikap, pendapat, atau perilaku komunikan yang lebih menekan sisi psikologis komunikan. Penekanan ini dimaksudkan untuk mengubah sikap, pendapat, atau perilaku, tetapi persuasi dilakukan dengan halus, luwes, yang mengandung sifatsifat manusiawi sehingga mengakibatkan kesadaran dan kerelaan yang disertai perasaan senang. ${ }^{33}$ Pada umumnya sikap-sikap individu/ kelompok yang hendak dipengaruhi ini terdiri dari tiga komponen: ${ }^{34}$

- Kognitif - perilaku dimana individu mencapai tingkat "tahu" pada objek yang diperkenalkan.

- Afektif - perilaku dimana individu mempunyi kecenderungan untuk suka atau tidak suka pada objek.

- Behavioral perilaku yang sudah sampai tahap hingga individu melakukan sesuatu (perbuatan) terhadap objek.

Tiga komponen inilah yang secara khusus di sentuh oleh TGH. Mukhtar Amin untuk membangun semangat berhaji, dengan penjabaran sebagai berikut:

Pada aspek kognitif, TGH. Mukhtar Amin memberikan pemahaman bahwa, pemahaman masyarakat tentang kewajiban berhaji itu hanya untuk orang yang mampu saja, adalah sesuatu yang keliru. Karena menurutnya, kalaupun umat Islam tidak mampu menunaikan ibadah haji secara finansial, yang harus ia lakukan adalah tetap belajar tentang ilmu haji itu sendiri, sebagai usaha untuk menunaikan kewajiban dari kesempurnaan rukun Islam.

\footnotetext{
${ }^{31}$ Anwar Arifin, Dakwah Kontemporer; Sebuah Studi Komunikasi, (Yogyakarta: Graha Ilmu, 2011), 77

${ }^{32}$ Wawancara, Mukhtar Amin, 10 September 2018

${ }^{33} \mathrm{https} / / /$ id.wikipedia.org/wiki/Komunikasi_persuasif

${ }^{34}$ Muhammad Sulthon, Desain Ilmu..., 16
} 
Selain itu TGH. Mukhtar Amin juga pentingnya usaha dari para jamaah untuk sedikit demi sedikit untuk menyisihkan rizki guna menunaikan ibadah haji, sembari berkeyakinan bahwa, berangkat atau tidaknya adalah perkara izin dari Allah SWT.

Pada aspek afektif. Dengan adanya pemahaman secara kognitif tentang urgensi ibadah haji, maka sikap jamaah majelis al-Mukhtariah menjadi berubah, dari awalnya acuh tak acuh pada persoalan haji, menjadi lebih terbuka dan tidak memandang sempit. Bahwa ibadah haji hanyalah panggilan bagi orang yang mampu secara ekonomi saja adalah pemahaman yang keliru, karena adanya keinginan untuk belajar ilmu manasik haji walaupun belum mampu secara materi, adalah bagian dari awal untuk memenuhi kewajiban berhaji itu sendiri.

Aspek Behavioral. Dalam kontek ini, pemahaman terhadap urgensi haji yang benar, disertai perubahan sikap dan cara pandang terhadap ibadah haji, akhirnya melahirkan perbuatan nyata dalam bentuk upaya-upaya melakukan ibadah haji secara nyata. Misalnya, melalui penyetoran dana tabungan haji secara resmi, atau berangkat haji dengan menggunakan jasa travel. Sejauh ini, jamaah majelis Ta'lim al-Mukhtariah sudah banyak yang menunaikan ibadah haji dan sebagian lagi sedang menunggu giliran panggilan dari pemerintah.

Pada dasarnya, kepercayaan atau pengetahuan seseorang tentang sesuatu dipercaya dapat memengaruhi sikap mereka dan pada akhirnya memengaruhi perilaku dan tindakan mereka terhadap sesuatu. Mengubah pengetahuan seseorang akan sesuatu dipercaya dapat mengubah perilaku mereka. Walaupun ada kaitan antara kognitif, afektif, dan behavioral, keterkaitan ini tidak selalu berlaku lurus atau langsung

\section{Kesimpulan}

Temuan penelitian ini menunjukkan bahwasanya: (1) TGH. Mukhtar Amin menggunakan komunikasi persuasif dalam membangun semangat berhaji jamaah majelis ta'lim al-Mukhtariah. Substansi utama dari komunikasi persuasif adalah, upaya menyadarkan masyarakat melalui upaya-upaya yang tidak memaksa, tetapi dengan langkah-langkah penyadaran secara rasional dan pendekatan psikologis. Misalnya, TGH. Mukhtar Amin menyadarkan kognisi masyarakat yang selama ini salah menafsirkan arti kewajiban berhaji, tidak dengan cara-cara yang memaksa, melainkan dengan cara memberikan gambaran yang sesungguhnya tentang urgensi ibadah haji, sehingga masyarakat dengan tanpa dipaksa memiliki gambaran yang seutuhnya tentang ibadah haji (2) TGH. Mukhtar Amin menyentuh tiga aspek utama jamaah dalam kaitannya dengan membangun semangat berhaji yang meliputi, aspek kognitif,aspek afektif dan aspek behavioral. Aspek kognitif mengacu pada penyadaran yang sifatnya merubah atau menambah pengetahuan, afektif berkaitan dengan perubahan sikap dan behavioural berkaitan dengan perubahan prilaku. Misalnya, TGH. Mukhtar Amin, memahamkan masyarakat tentang arti kewajiban berhaji, sehingga melahirkan perubahan sikap jamaah terhadap arti haji yang sesungguhnya, kemudian itu dibarengi dengan perubahan prilaku jamaah yang berusaha untuk belajar ilmu haji sekaligus menyetorkan sebagian harta mereka untuk menunaikan ibadah haji.

\section{DAFTAR PUSTAKA}

Aziz,Ali. 2012. Ilmu Dakwah (Ed) Revisi Cet. ke-3, Jakarta: Prenada Media Group

Arifin,Anwar. 2011. Dakwah Kontemporer; Sebuah Studi Komunikasi, (Yogyakarta: Graha Ilmu

Asnawi, 2006. Agama Dan Paradigm Sosial: Menyingkap Pemahaman Masyarakat Sasak tentang Takdir Allah dan Kematian Bayi, Jakarta: Sentra Media

Aripudin,Acep. 2011. Pengembangan Metode Dakwah; Respon Da'i Terhadap Dinamika Kehidupan Beragama di Kaki Ciremai, Jakarta: PT RajaGrafindo Persada. 
Nasrullah,Rulli. 2014. Komunikasi Antar Budaya: Di Era Budaya Siber, (Jakarta: Kencana Prenadamedia Group.

Mulyana,Deddy. 2008. Ilmu Komunikasi; Suatu Pengantar, Cet ke-12 Bandung: PT Remaja Rosdakarya.

H. A.W. Widjadja, 2002. Komunikasi: Komunikasi dan Hubungan Masyarakat, (Jakarta: PT Bumi Aksara.

Ismail,lyas \& Hotman,Prio. 2011. Filsafat Dakwah: Rekayasa Membangun Agama dan Peradaban Islam, Jakarta: Kencana Prenada Media Group.

Kamus Besar Bahasa Indonesia

Sulthon, Muhammad.2003. Desain Ilmu Dakwah Kajian Ontologis, Epistimologis, dan Aksiologis, Yogyakarta: Pustaka Pelajar

Ilaihi,Wahyu. 2010. Komunikasi Dakwah, Bandung, PT Remaja Rosdakarya

Hendropuspito, 1983. Sosiologi Agama, Yogyakarta: Penerbit Kanisius 